\title{
Groundwater Quality Assessment in Wadi Tharad Area Southern Saudi Arabia
}

\author{
Masoud E. Al-Ahmadi* and Nasr S. Aljahdali** \\ *Faculty of Earth Sciences, King Abdulaziz University, \\ Jeddah, Saudi Arabia \\ **BRGM, Jeddah, Saudi Arabia
}

Received: 16/6/97 Revised: 8/5/99 Accepted: 28/6/99

\begin{abstract}
Hydrochemical study is carried out on Wadi Tharad area in south of Saudi Arabia, where 42 wells were chosen for collection of water samples. The electrical conductivity and $\mathrm{pH}$ of the collected samples are measured in the field. The water samples are chemically analyzed and the major cations and anions are determined. The water salinity ranges from $351 \mathrm{mg} / \mathrm{l}$ to $3137 \mathrm{mg} / \mathrm{l}$.

The results of the chemical analyses show that most of the cations and anions fall within the World Health Organization (WHO) standards and the water can be used safely in some locations. The groundwater in the study area is divided into two hydrochemical facies: 1) calcium-magnesium-sulfate-chloride and 2) calcium-magnesiumbicarbonate. The SAR ratios are calculated and found to be ranging from 1.15 to 5.34 and hence the water is very suitable for irrigation purposes.
\end{abstract}

\section{Introduction}

Groundwater is very important for human life especially in arid regions where the evaporation rates are high, the resources are limited, and recharge from surface to any aquifer is very small. So, from this point, the groundwater is considered to be the main resource in arid countries like Saudi Arabia. In Saudi Arabia, the increase on water demand is mainly due to the increase in the agricultural activities. Other related factors are facilities granted by the government to the farmers including free tax loans, land rentals in low prices and purchase of agricultural products from farmers in reasonable prices. Consequently, 
in cases where there is not enough natural recharge to groundwater reservoirs, the quality of water deteriorates by time. Hence, it became necessary to evaluate the hydrogeochmistry of the groundwater resources for drinking or agricultural purposes in Wadi Tharad area which lies between longitudes $41^{\circ} 25^{\prime} \mathrm{E}$ and $41^{\circ}$ $40^{\prime} \mathrm{E}$ and latitudes $20^{\circ} 15^{\prime} \mathrm{N}$ and $20^{\circ} 20^{\prime} \mathrm{N}$ (Fig. 1).

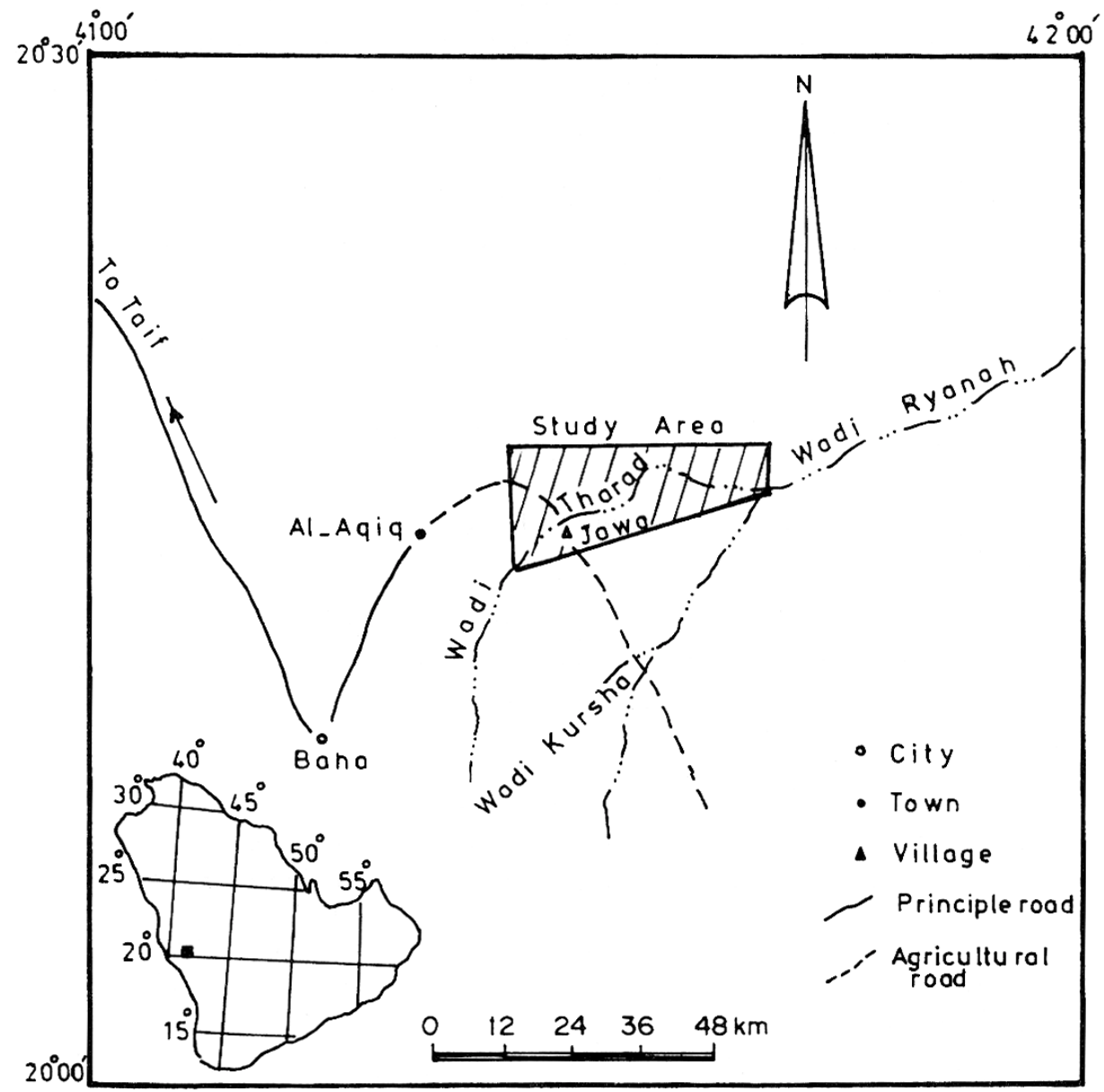

Fig. 1. Location map.

The climate in the study area is hot during the summer and cold in the winter, with temperature ranging between $13^{\circ} \mathrm{C}$ and $25^{\circ} \mathrm{C}$. The average annual rainfall during ten years (1972-1982) was $442 \mathrm{~mm}$, and it falls usually in summer, spring and winter seasons with the maximum reaching $75 \mathrm{~mm}$ in winter. The annual evaporation is between 2000 to $2500 \mathrm{~mm}$, and the relative humidity ranges from $65 \%$ in mountain area to $30 \%$ in desert, (Water Atlas of Saudi Arabia, 1984). 


\section{Geology and Hydrogeology}

The study area is located at the southern part of the Precambrian Arabian Shield, which occupies the western parts of the Kingdom. The shield is characterized by four structure movements among which Najd Fault system plays a dominant role (Greenwood, 1975). The area was tectonically inactive during the upper Tertiary period. Wadi Tharad coarse extends in an East-West direction crossing igneous and metamorphic rocks with the metamorphic units being the major rock types. The drainage system is of dendritic type and the wadi varies in width from one place to another with an average width of $100 \mathrm{~m}$.

The study area includes the following rock types:

1 - Precambrian rocks: These rocks belong to Jeddah Group and it can be divided into two formations:

A) Ketenha Formation: It is composed of andesitic rocks, arkose, marble, andesite, breccia and green schist.

B) Kursha Formation: It consists of metamorphic rocks of the green schist type.

The study area is also cut by some dykes of andesitic and basaltic composition (Fig. 2).

2) Recent deposits: These deposits belong to the Quaternary period and consist of sand and gravel. The coarse grained deposits are present at the edges of the wadi, and the fine and medium grained deposits occur in the middle of the wadi.

Structurally, the area has been deformed by tectonic activities like Hijaz movement which left imprints of some faults and folds (Greenwood, 1975). Most of the faults extend in a north-south and a northeast-southwest directions.

The main aquifer in the study area is present in the Recent deposits and is unconfined in nature. The depth to water table varies from 2.2 to $11.8 \mathrm{~m}$. The wells have total depths that vary between 3.98 and $12.12 \mathrm{~m}$, and the diameter ranges from 2.5 to $4 \mathrm{~m}$. The permeability value ranges between 0.0001 and $0.04 \mathrm{~m} /$ day and the average transmissivity and storage coefficient values are $0.06 \mathrm{~m}^{2} / \mathrm{d}$ and 0.03 respectively (Asfri, 1993).

\section{Hydrochemical Data}

About 42 groundwater samples were collected in plastic bottles from different locations (Fig. 3) in the study area for chemical analyses. The electrical conductivity (EC) and $\mathrm{pH}$ of the collected samples were measured in the field. The major cations and anions were determined for each sample using Flame Pho- 


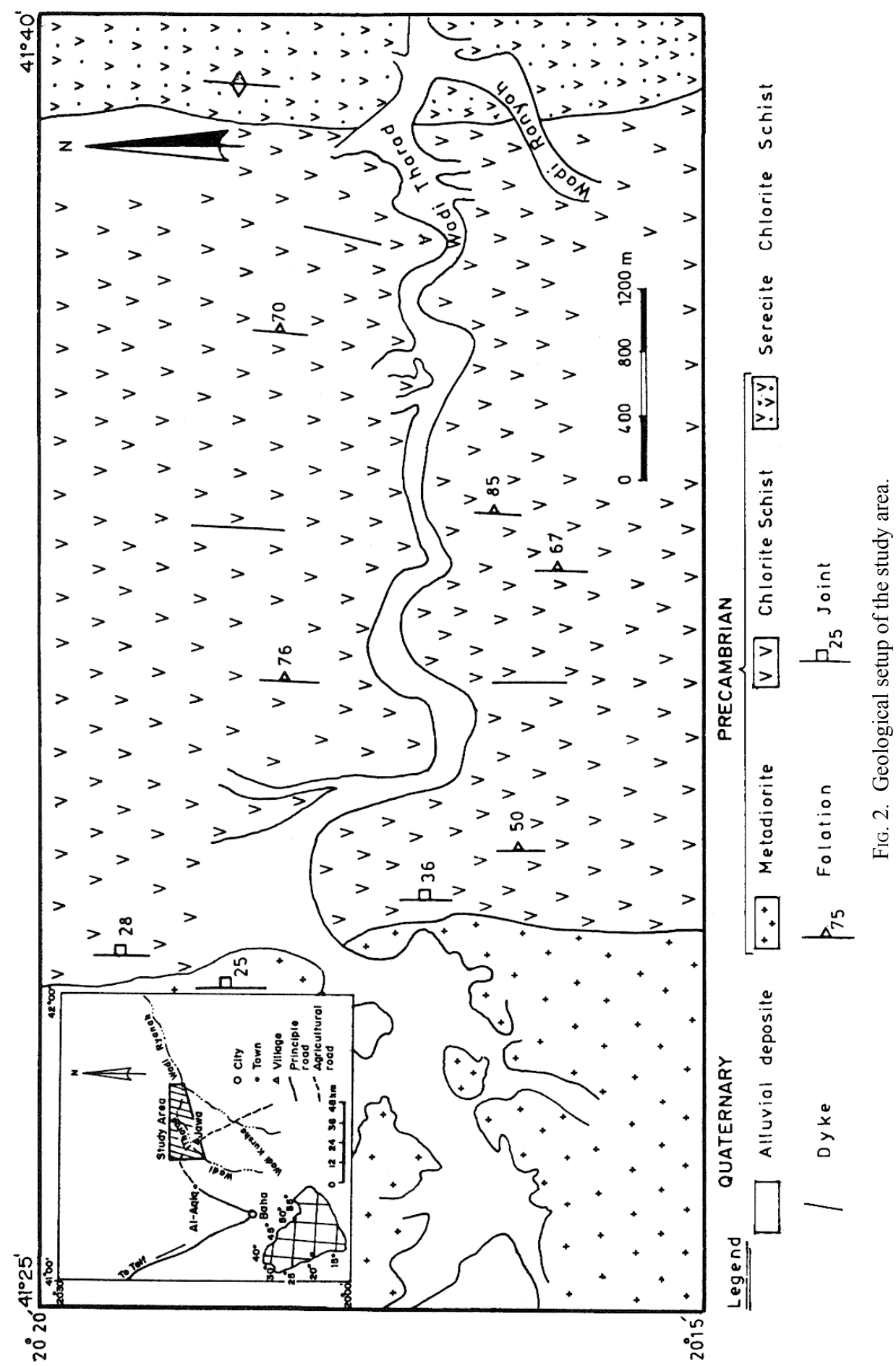


Groundwater Quality Assessment in...

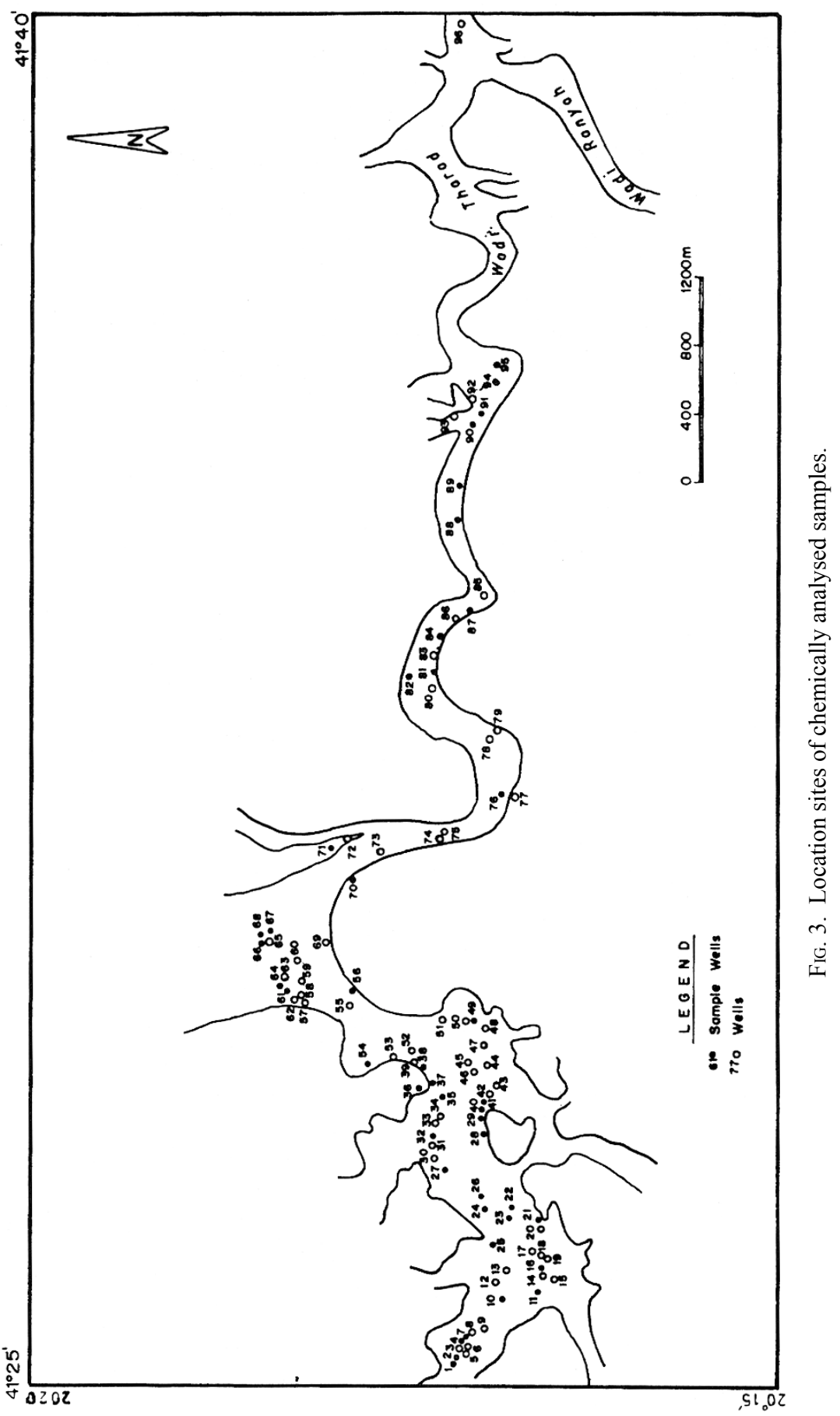


tometer for $\mathrm{Na}^{+}$and $\mathrm{K}^{+}$, while the $\mathrm{Ca}^{++}, \mathrm{Mg}^{++}, \mathrm{HCO}_{3}^{-}, \mathrm{SO}_{4}^{--}$and $\mathrm{Cl}^{-}$concentrations were determined through standard methods. Among these methods are titration with EDTA for calcium and magnesium, and chloride titration with mercury nitrate. The bicarbonate determination is achieved by the titration with $0.01 \mathrm{~N}$ sulfuric acid. Finally the turbidity method was used for the sulfate analysis.

\section{Distance-Quality Diagrams}

The numerical results of the field measurements and the chemical analysis data of the water samples are summarized in Table 1. Prior to any interpretation, these chemical analysis data are checked for ionic balance in each well. It is observed that the total cations and total anions, in epm, do not differ more than $10 \%$.

TABLE 1. Chemical analysis of groundwater in the area.

\begin{tabular}{|c|c|c|c|c|c|c|c|c|c|c|c|}
\hline $\begin{array}{c}\text { Well } \\
\text { no. }\end{array}$ & $\begin{array}{c}\mathrm{Ca}^{++} \\
(\mathrm{mg} / \mathrm{l})\end{array}$ & $\begin{array}{c}\mathrm{Mg}^{++} \\
(\mathrm{mg} / \mathrm{l})\end{array}$ & $\begin{array}{c}\mathrm{Na}^{+} \\
(\mathrm{mg} / \mathrm{l})\end{array}$ & $\begin{array}{c}\mathrm{K}^{+} \\
(\mathrm{mg} / \mathrm{l})\end{array}$ & $\begin{array}{c}\mathrm{Cl}^{-} \\
(\mathrm{mg} / \mathrm{l})\end{array}$ & $\begin{array}{c}\mathrm{HCO}_{3}^{-} \\
(\mathrm{mg} / \mathrm{l})\end{array}$ & $\begin{array}{c}\mathrm{SO}_{4}^{--} \\
(\mathrm{mg} / \mathrm{l})\end{array}$ & $\begin{array}{c}\mathrm{TDS} \\
(\mathrm{mg} / \mathrm{l})\end{array}$ & $\mathrm{pH}$ & $\begin{array}{c}\mathrm{EC} \\
(\mu \mathrm{S} / \mathrm{cm})\end{array}$ & $\mathrm{SAR}$ \\
\hline 1 & 36.87 & 17.51 & 38.00 & 2.00 & 42.54 & 170.80 & 77.22 & 384.9 & 7.5 & 566 & 1.29 \\
\hline 2 & 43.29 & 18.48 & 39.00 & 2.00 & 35.45 & 195.20 & 41.16 & 374.6 & 7.3 & 551 & 1.25 \\
\hline 7 & 40.08 & 29.18 & 39.00 & 2.00 & 53.18 & 170.80 & 82.32 & 416.6 & 7.5 & 613 & 1.15 \\
\hline 10 & 57.72 & 8.76 & 37.00 & 2.00 & 35.45 & 170.80 & 41.16 & 352.9 & 7.2 & 519 & 1.42 \\
\hline 11 & 62.52 & 44.17 & 104.00 & 3.00 & 141.80 & 268.40 & 123.48 & 747.4 & 7.7 & 1099 & 2.45 \\
\hline 16 & 76.94 & 39.88 & 176.00 & 3.00 & 226.88 & 341.60 & 329.28 & 1193.6 & 8.0 & 1755 & 4.06 \\
\hline 21 & 105.81 & 53.50 & 209.00 & 3.00 & 389.55 & 292.80 & 61.24 & 1115.3 & 8.3 & 1640 & 4.13 \\
\hline 22 & 80.16 & 34.05 & 149.00 & 3.00 & 233.97 & 256.20 & 205.80 & 962.2 & 7.7 & 1415 & 3.51 \\
\hline 23 & 40.08 & 17.51 & 37.00 & 2.00 & 42.54 & 170.80 & 41.16 & 351.1 & 7.1 & 516 & 1.23 \\
\hline 24 & 56.11 & 18.48 & 40.00 & 1.00 & 49.63 & 195.20 & 41.16 & 401.6 & 7.2 & 591 & 1.18 \\
\hline 25 & 150.70 & 46.69 & 98.00 & 5.00 & 134.71 & 317.20 & 329.29 & 1081.6 & 7.7 & 1591 & 1.79 \\
\hline 26 & 168.34 & 49.61 & 104.00 & 5.00 & 141.80 & 366.00 & 205.80 & 1040.5 & 7.9 & 1530 & 1.81 \\
\hline 27 & 112.22 & 38.91 & 98.00 & 5.00 & 170.16 & 195.20 & 41.16 & 660.7 & 7.6 & 972 & 2.03 \\
\hline 28 & 86.57 & 52.53 & 80.00 & 3.00 & 113.44 & 268.40 & 205.80 & 809.7 & 7.5 & 1191 & 1.67 \\
\hline 29 & 113.83 & 48.64 & 100.00 & 4.00 & 198.52 & 244.00 & 246.96 & 955.9 & 7.6 & 1400 & 1.98 \\
\hline 32 & 44.89 & 27.24 & 39.00 & 1.00 & 49.63 & 195.20 & 41.16 & 398.1 & 7.2 & 585 & 1.53 \\
\hline 35 & 51.30 & 17.51 & 40.00 & 1.00 & 49.63 & 195.20 & 41.16 & 395.8 & 6.9 & 582 & 1.22 \\
\hline
\end{tabular}


TABLE 1. (Continued)

\begin{tabular}{|c|c|c|c|c|c|c|c|c|c|c|c|}
\hline $\begin{array}{c}\text { Well } \\
\text { no. }\end{array}$ & $\begin{array}{l}\mathrm{Ca}^{++} \\
(\mathrm{mg} / \mathrm{l})\end{array}$ & $\begin{array}{l}\mathrm{Mg}^{++} \\
(\mathrm{mg} / \mathrm{l})\end{array}$ & $\begin{array}{c}\mathrm{Na}^{+} \\
(\mathrm{mg} / \mathrm{l})\end{array}$ & $\begin{array}{c}\mathrm{K}^{+} \\
(\mathrm{mg} / \mathrm{l})\end{array}$ & $\underset{(\mathrm{mg} / \mathrm{l})}{\mathrm{Cl}^{-}}$ & $\begin{array}{c}\mathrm{HCO}_{3}^{-} \\
(\mathrm{mg} / \mathrm{l})\end{array}$ & $\begin{array}{l}\mathrm{SO}_{4}^{--} \\
(\mathrm{mg} / \mathrm{l})\end{array}$ & $\begin{array}{c}\text { TDS } \\
(\mathrm{mg} / \mathrm{l})\end{array}$ & $\mathrm{pH}$ & $\begin{array}{c}\mathrm{EC} \\
(\mu \mathrm{S} / \mathrm{cm})\end{array}$ & SAR \\
\hline 36 & 161.92 & 67.12 & 139.00 & 2.00 & 248.15 & 366.00 & 370.44 & 1354.6 & 7.7 & 1992 & 3.32 \\
\hline 37 & 62.93 & 20.32 & 58.25 & 1.50 & 70.00 & 195.20 & 75.86 & 484.1 & 7.9 & 712 & 1.65 \\
\hline 38 & 48.10 & 23.35 & 40.00 & 1.00 & 49.63 & 195.20 & 41.16 & 398.4 & 7.2 & 586 & 1.18 \\
\hline 41 & 91.38 & 22.37 & 79.00 & 3.00 & 134.71 & 244.00 & 82.32 & 656.8 & 7.9 & 960 & 1.92 \\
\hline 49 & 86.57 & 38.91 & 73.00 & 2.00 & 134.71 & 195.20 & 164.64 & 695.0 & 7.6 & 1022 & 1.64 \\
\hline 54 & 237.27 & 75.88 & 174.00 & 3.00 & 588.47 & 268.40 & 411.60 & 1758.6 & 7.7 & 2580 & 5.34 \\
\hline 56 & 344.69 & 92.42 & 193.00 & 4.00 & 765.72 & 244.00 & 493.92 & 2137.7 & 7.8 & 3144 & 2.39 \\
\hline 61 & 163.53 & 50.59 & 117.00 & 3.00 & 290.69 & 268.40 & 246.96 & 1140.1 & 7.6 & 1677 & 2.05 \\
\hline 64 & 128.26 & 33.08 & 88.00 & 2.00 & 205.61 & 219.60 & 205.80 & 882.3 & 7.5 & 1298 & 1.79 \\
\hline 66 & 221.24 & 70.04 & 148.00 & 3.00 & 397.04 & 292.80 & 411.60 & 1543.7 & 7.6 & 2270 & 2.22 \\
\hline 67 & 128.26 & 41.83 & 103.00 & 3.00 & 212.70 & 244.00 & 246.96 & 979.8 & 7.5 & 1441 & 2.16 \\
\hline 68 & 149.10 & 45.72 & 115.00 & 3.00 & 262.33 & 244.00 & 288.12 & 1107.3 & 8.3 & 1628 & 2.11 \\
\hline 70 & 166.73 & 47.67 & 105.00 & 2.00 & 290.00 & 219.60 & 288.12 & 1119.8 & 8.3 & 1647 & 1.85 \\
\hline 71 & 105.81 & 29.18 & 88.00 & 3.00 & 170.16 & 219.60 & 164.64 & 780.4 & 7.7 & 1148 & 1.95 \\
\hline 76 & 136.27 & 37.94 & 90.00 & 3.00 & 219.79 & 244.00 & 205.80 & 936.8 & 7.6 & 1378 & 1.76 \\
\hline 81 & 163.53 & 50.59 & 151.00 & 3.00 & 375.77 & 219.60 & 370.44 & 1333.9 & 7.1 & 1962 & 2.24 \\
\hline 82 & 133.07 & 46.69 & 114.00 & 3.00 & 226.88 & 244.00 & 329.28 & 1096.9 & 8.0 & 1613 & 2.17 \\
\hline 84 & 89.78 & 27.24 & 78.00 & 3.00 & 170.16 & 146.40 & 164.64 & 679.2 & 7.1 & 999 & 1.85 \\
\hline 87 & 221.00 & 88.53 & 150.21 & 3.00 & 397.04 & 268.40 & 329.28 & 1457.4 & 7.3 & 2143 & 2.53 \\
\hline 88 & 134.67 & 54.48 & 108.00 & 3.00 & 219.79 & 219.60 & 246.96 & 986.5 & 7.5 & 1451 & 1.99 \\
\hline 89 & 113.83 & 33.08 & 88.00 & 2.00 & 184.34 & 195.20 & 312.20 & 928.6 & 7.2 & 1366 & 1.87 \\
\hline 90 & 113.83 & 37.94 & 109.00 & 3.00 & 184.34 & 219.60 & 205.80 & 873.5 & 7.2 & 1285 & 2.26 \\
\hline 91 & 107.41 & 29.18 & 77.00 & 2.00 & 163.07 & 195.20 & 123.48 & 697.4 & 7.4 & 1026 & 1.70 \\
\hline 94 & 104.21 & 32.10 & 80.00 & 3.00 & 163.07 & 195.20 & 205.80 & 783.4 & 7.2 & 1152 & 1.76 \\
\hline 95 & 211.62 & 93.39 & 211.00 & 5.00 & 446.67 & 122.00 & 782.04 & 1871.7 & 7.4 & 2753 & 3.04 \\
\hline
\end{tabular}

Table 2 shows the correlation between the chemical analysis results and the World Health Organization standards (WHO) for drinking water. It is obvious from this table that the $\mathrm{Ca}^{++}$concentration ranges between 36.9 and $344.7 \mathrm{mg} / 1$, 
which is below the WHO standard. The variation of the $\mathrm{Ca}^{++}$with distance along Wadi Tharad is shown in Fig. 4a. The origin of distance corresponds to a point in the downstream section near well No. 1. It appears from Fig. 4a that the values of calcium show high variations in the upstream sections and comparatively stable variations towards the downstream sections and reach a maximum value at well No. 56. This could be due to the specific location of this well which is drilled at the edge of the wadi where the rock is highly fractured. The fractures may have discharged calcium-rich water to the main wadi, which is relatively low in calcium concentration. The initial calcium fluctuation has an increasing trend but it stabilizes after the well number 56 with minor fluctuations. This could be due to the change in the lithology of the country rocks.

TABLE 2. Correlation between the range of composition of groundwater in the study area and WHO standard for drinking water (WHO, 1984).

\begin{tabular}{|l|c|l|}
\hline Parameter & Range & WHO \\
\hline $\mathrm{TDS}(\mathrm{mg} / \mathrm{l})$ & $351.0-2137.7$ & 1000 \\
\hline $\mathrm{pH}$ & $6.9-8.3$ & $6.5-8.5$ \\
\hline $\mathrm{EC}(\mu \mathrm{s} / \mathrm{cm})$ & $519.0-3144$ & 1400 \\
\hline $\mathrm{Ca}^{++}(\mathrm{mg} / \mathrm{l})$ & $36.9-344.7$ & $500 \mathrm{as} \mathrm{caco}_{3}$ \\
\hline $\mathrm{Mg}^{++} "$ & $8.8-93.4$ & \\
\hline $\mathrm{Na}^{+} "$ & $37.0-211.0$ & 200 \\
\hline $\mathrm{K}^{+} "$ & $1.0-5.0$ & \\
\hline $\mathrm{HCO}_{3}^{--} "$ & $122.0-366.0$ & \\
\hline $\mathrm{SO}_{4}^{--} "$ & $41.2-782.0$ & 400 \\
\hline $\mathrm{Cl}^{-} "$ & $35.5-765.7$ & 250 \\
\hline
\end{tabular}

The $\mathrm{Mg}^{++}$concentrations in the study area ranges from 8.8 to $93.4 \mathrm{mg} / \mathrm{l}$, which are not very high. Fig. $4 \mathrm{~b}$ shows an obvious increasing trend along the wadi. Again, there is quite often variability at the upstream sections whereas in the downstream sections, the frequency of variation decreases while the $\mathrm{Mg}^{++}$ concentration increases. These could be due to the weathering of the metamorphic rocks, which cover the area.

The values of $\mathrm{Na}^{+}$concentration lie within the permissible limits for drinking water except for two samples having values slightly above the WHO values (Fig. $4 \mathrm{c}$ and Table 2). On the other hand, the values of $\mathrm{Na}^{+}$along Wadi Tharad 

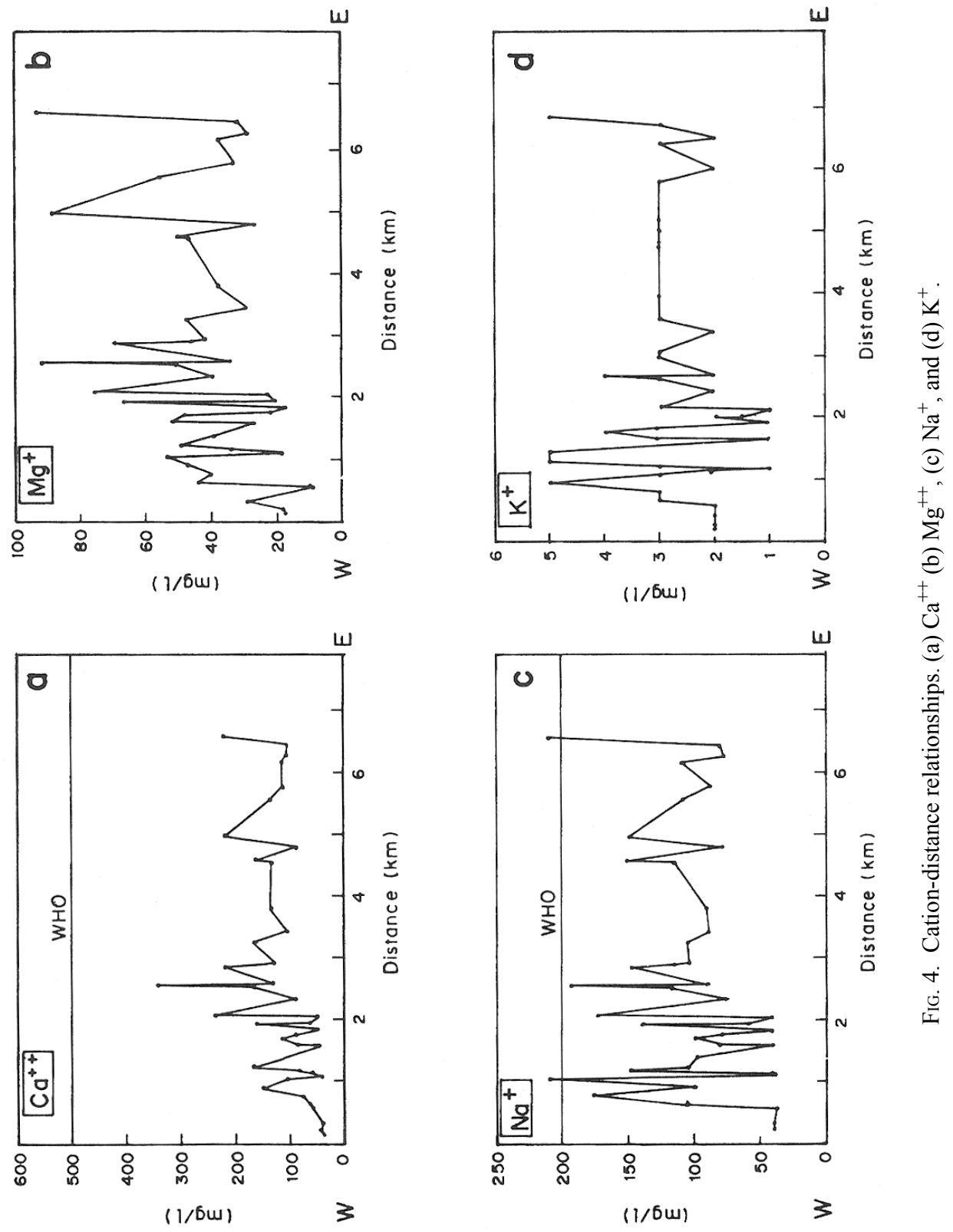
also fluctuate from west to east. The reason of $\mathrm{Na}^{+}$presence may be due to the dissolution of rocks which have clay minerals such as schist and rocks with Naplagioclase like diorite. A common feature to all the cations in Fig. 4 are that they have higher frequency of fluctuations at the upstream and this frequency decreases towards the downstream. This is due to the fact that more occasional rainfall occurs in the upstream sections as a result of which the cations concentration changes by infiltrating water.

Finally, the $\mathrm{K}^{+}$is the least abundant of the cations, and its concentration range from 1 to $5 \mathrm{mg} / \mathrm{l}$ (Table 2) which is considered as normal by the WHO standards. On the other hand, the change of $\mathrm{K}^{+}$along the wadi fluctuates but with no obvious trend.

Among the anions, $\mathrm{Cl}^{-}, \mathrm{HCO}_{3}^{-}$and $\mathrm{SO}_{4}^{-}$are abundant in all the water samples throughout the study area. The change of these anions with distance is represented in Fig. 5. For instance, $\mathrm{Cl}^{-}$is found to be less than WHO standard in 32 samples. The reason of high concentrations in ten other samples may be due to the location of these wells, which are drilled in the basement rocks such as well No. 56 having the highest value of chloride among all wells. It can also be seen that this well is drilled in chlorite schist, which may yield rather high levels of chloride. The concentrations of $\mathrm{Cl}^{-}$change from high to low values, as one goes along Wadi Tharad (Fig. 5a). The vertical hydraulic gradient is equal to zero whereas the horizontal gradient is almost negligible at the basement rock. This implies very small Darcy velocity and consequently increase in $\mathrm{Cl}^{-}$concentrations.

The bicarbonate values along the wadi (Fig. 5b) vary between 122 and 366 $\mathrm{mg} / \mathrm{l}$. These values seem to be high but they are in the range of the most commonly acceptable limits (Davis and DeWiest, 1976).

The concentrations of $\mathrm{SO}_{4}^{--}$(Fig. 5c) have a wide range of variability in the study area, but it can also be seen that about 39 water samples (92\%) lie below the WHO standard, while only three samples exceed that value. It is possible to say that the water is good for drinking with respect to $\mathrm{SO}_{4}^{--}$. On the other hand, the values of $\mathrm{SO}_{4}^{--}$concentrations in upstream sections are comparatively lower, but became high at the last well location.

In order to determine salinization, the ratios of $\mathrm{Ca}^{++} / \mathrm{Mg}^{++}, \mathrm{Ca}^{++} / \mathrm{Cl}^{-}$and $\mathrm{Na}^{+} / \mathrm{Cl}^{-}$were calculated from the available data (Table 3). It is obvious that the $\mathrm{Ca}^{++} / \mathrm{Mg}^{++}$ratio has high ratios $(>1.0)$ in all the samples. This indicates the high concentration of $\mathrm{Ca}^{++}$with respect to $\mathrm{Mg}^{++}$, and it could be due to the contact with igneous and metamorphic rocks which cover the whole study area. However, the ratio of $\mathrm{Ca}^{++} / \mathrm{Cl}^{-}$is less than 1.0 except in six water samples. The majority of $\mathrm{Na}^{++} / \mathrm{Cl}^{-}$ratios fall below 1.0 indicating fresh water existence and 

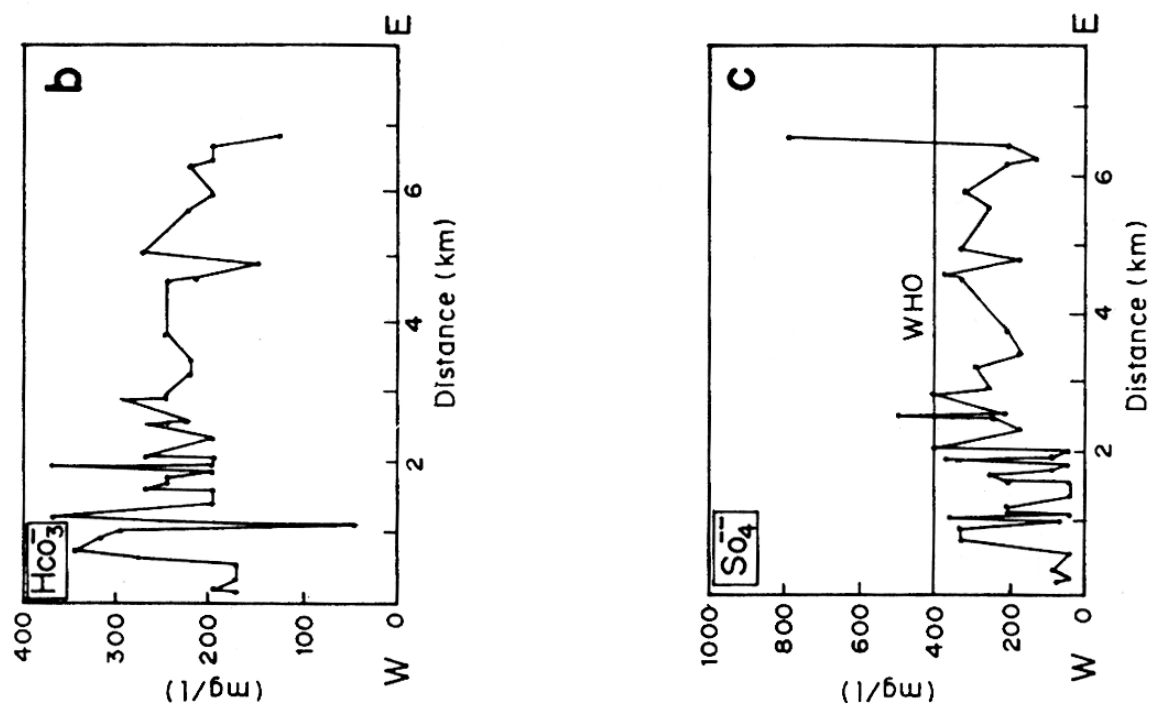

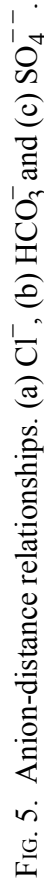

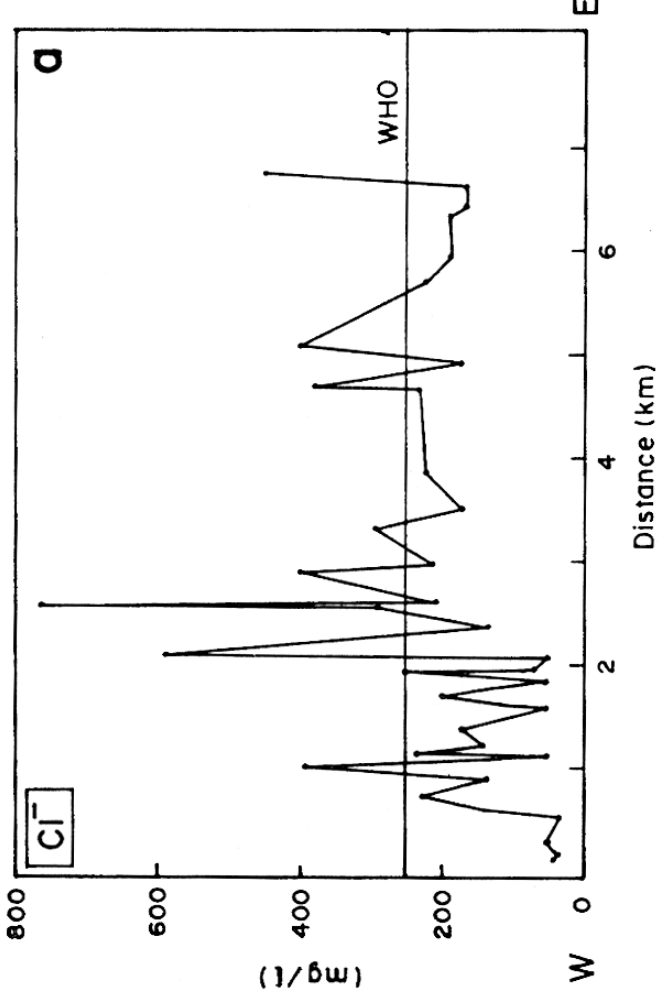


also below 0.87 as seawater except for three samples, namely samples Nos. 1, 2 and 10. The concentration of $\mathrm{Cl}^{-}$in sample 1 is more than $\mathrm{Na}^{+}$, where in samples 2 and 10 the concentration of $\mathrm{Na}^{+}$is still larger than $\mathrm{Cl}^{-}$but it is just above the value of 1.0 .

TABLE 3. Ratio values for some ions.

\begin{tabular}{|c|c|c|c|}
\hline Well number & $\mathrm{Ca}^{++} / \mathrm{Mg}^{++}$ & $\mathrm{Ca}^{++} / \mathrm{Cl}^{-}$ & $\mathrm{Na}^{+} / \mathrm{Cl}^{-}$ \\
\hline 1 & 2.11 & 0.87 & 0.89 \\
\hline 2 & 2.34 & 1.22 & 1.10 \\
\hline 7 & 1.37 & 0.75 & 0.73 \\
\hline 10 & 6.59 & 1.63 & 1.04 \\
\hline 11 & 1.42 & 0.44 & 0.73 \\
\hline 16 & 1.93 & 0.34 & 0.76 \\
\hline 21 & 1.98 & 0.27 & 0.54 \\
\hline 22 & 2.35 & 0.34 & 0.64 \\
\hline 23 & 2.29 & 0.94 & 0.87 \\
\hline 24 & 3.04 & 1.13 & 0.81 \\
\hline 25 & 3.23 & 1.12 & 0.73 \\
\hline 26 & 3.39 & 1.19 & 0.73 \\
\hline 27 & 2.88 & 0.66 & 0.58 \\
\hline 28 & 1.65 & 0.76 & 0.71 \\
\hline 29 & 2.34 & 0.57 & 0.50 \\
\hline 32 & 1.65 & 0.90 & 0.79 \\
\hline 35 & 2.93 & 1.03 & 0.81 \\
\hline 36 & 2.41 & 0.65 & 0.65 \\
\hline 37 & 1.01 & 0.90 & 0.83 \\
\hline 38 & 2.06 & 0.97 & 0.81 \\
\hline 41 & 4.08 & 0.68 & 0.59 \\
\hline 49 & 2.23 & 0.64 & 0.54 \\
\hline 54 & 3.13 & 0.40 & 0.30 \\
\hline 56 & 3.73 & 0.45 & 0.25 \\
\hline 61 & 3.23 & 0.56 & 0.40 \\
\hline
\end{tabular}


TABLE 3. (Continued)

\begin{tabular}{|c|c|c|c|}
\hline Well number & $\mathrm{Ca}^{++} / \mathrm{Mg}^{++}$ & $\mathrm{Ca}^{++} / \mathrm{Cl}^{-}$ & $\mathrm{Na}^{+} / \mathrm{Cl}^{-}$ \\
\hline 64 & 3.88 & 0.62 & 0.43 \\
\hline 66 & 3.16 & 0.56 & 0.37 \\
\hline 67 & 3.07 & 0.60 & 0.48 \\
\hline 68 & 3.26 & 0.57 & 0.44 \\
\hline 70 & 3.50 & 0.57 & 0.36 \\
\hline 71 & 3.62 & 0.62 & 0.52 \\
\hline 76 & 3.59 & 0.62 & 0.41 \\
\hline 81 & 3.23 & 0.44 & 0.40 \\
\hline 82 & 2.85 & 0.59 & 0.50 \\
\hline 84 & 3.30 & 0.53 & 0.46 \\
\hline 87 & 2.50 & 0.56 & 0.38 \\
\hline 88 & 2.47 & 0.61 & 0.49 \\
\hline 89 & 3.44 & 0.62 & 0.48 \\
\hline 90 & 3.00 & 0.62 & 0.59 \\
\hline 91 & 3.68 & 0.66 & 0.57 \\
\hline 94 & 3.25 & 0.64 & 0.49 \\
\hline 95 & 2.27 & 0.47 & 0.47 \\
\hline
\end{tabular}

\section{Trilinear Diagram and Composite Quality Values}

Figure 6 illustrates the presentation of the chemical analysis data from the study area in the form of trilinear (Piper) diagram from which it can be seen that the dominant cations are calcium and magnesium, while the chloride and sulfate are the dominant anions. In terms of Piper classification, the waters in this area have 3 main sources of cations and anions as follows:

(a) alkaline earth exceeds alkalies.

(b) strong acid exceeds alkalies and

(c) no one of the cations-anions pairs exceeds $50 \%$

The hydrochemical facies have been determined as forming through the interaction between rocks and water along the ground water flow path and it shows that the area has two major types of groundwater: calcium-magnesium-sulfatechloride water and calcium-magnesium-bicarbonate water. 


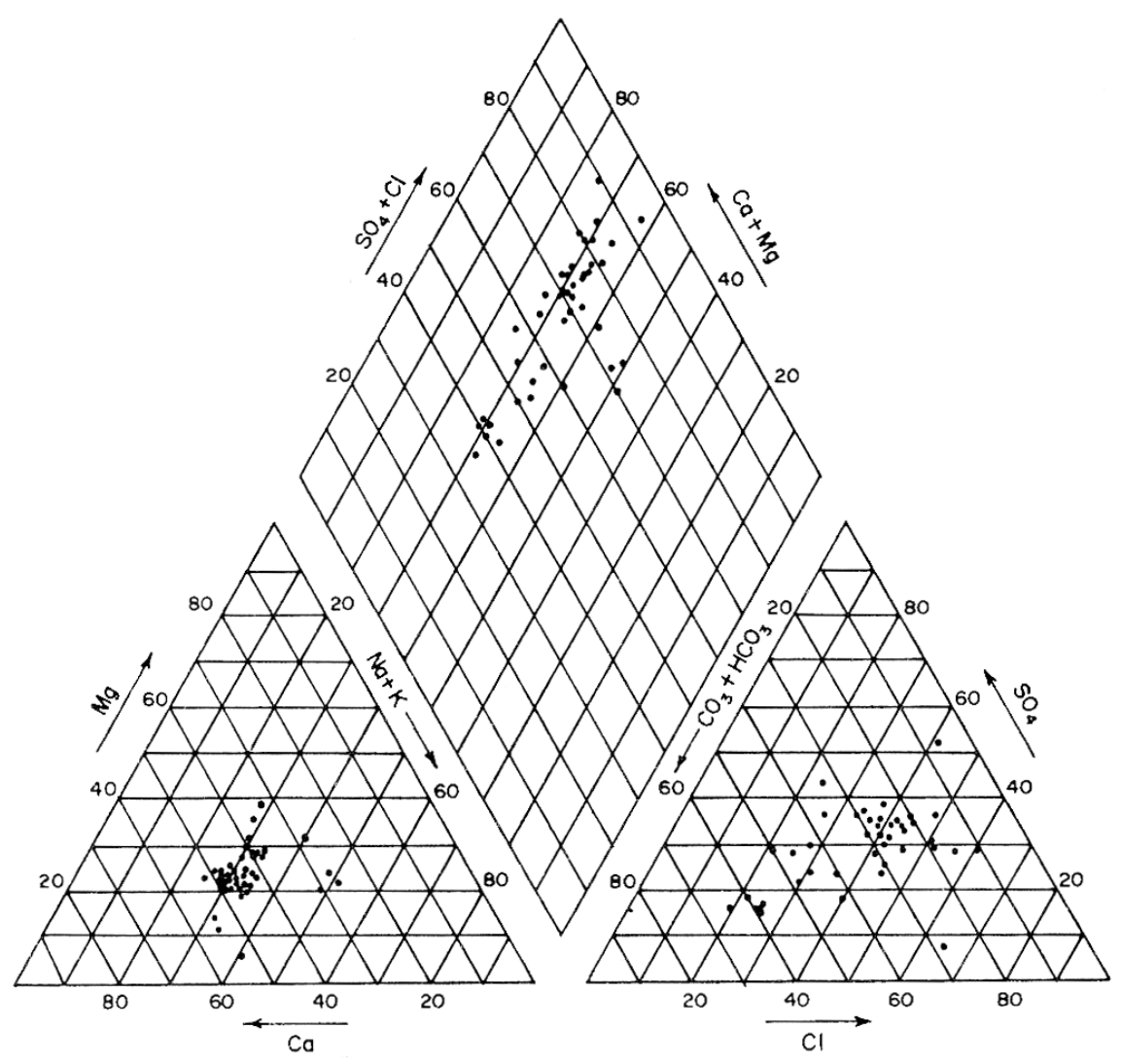

FIG. 6. Trilinear (Piper) diagram for the chemical composition of the groundwater samples.

Among the composite quality values electrical conductivity (EC) changes in big scale especially away from the center of the wadi. This may be due to many reasons, such as the well penetration to the metamorphic rocks, which give the chance for the groundwater during movement to dissolve more minerals. It could also be due to the contamination by seepage especially in the wells drilled within the fractured rocks. Furthermore, evaporation also plays significant role as a result of temperature increase. The values of EC in this area range between 519 and $2753 \mu \mathrm{S} / \mathrm{cm}$, which are well over the WHO standard. In addition, about $55 \%$ of the samples are below the standard. The measurement of EC is important for indicating the salinity, which greatly affects the taste of water.

Another composite value, Total Dissolved Solid (TDS) is a general indicator in the determination of the water suitability (Driscoll, 1987). As shown in Table 2 , the TDS of the area can be divided into two categories: First, those that have 
less than $1000 \mathrm{mg} / \mathrm{l}$ (20 water samples) are fresh water according to TDS classification by Freeze and Cherry (1979) and can be used for drinking purposes. Second, those that have values larger than $1000 \mathrm{mg} / 1$ (22 water samples) and are classified as brackish water, although some of these values are just above 1000 $\mathrm{mg} / \mathrm{l}$. It can be stated that most of the groundwater in Wadi Tharad area is safely usable for drinking purposes particularly in locations with low TDS values. In the locations with higher TDS values than WHO standard, they can be exploited and used for irrigation and other purposes only.

Due to the importance of the obvious relationship between the EC and TDS, it was necessary to obtain its analytical form for the study area. Such relationship is valid for this wadi only, and is presented in Fig. 7 The scatter of points indicates a strong linear relationship. The representative equation is obtained from the classical least square regression technique as:

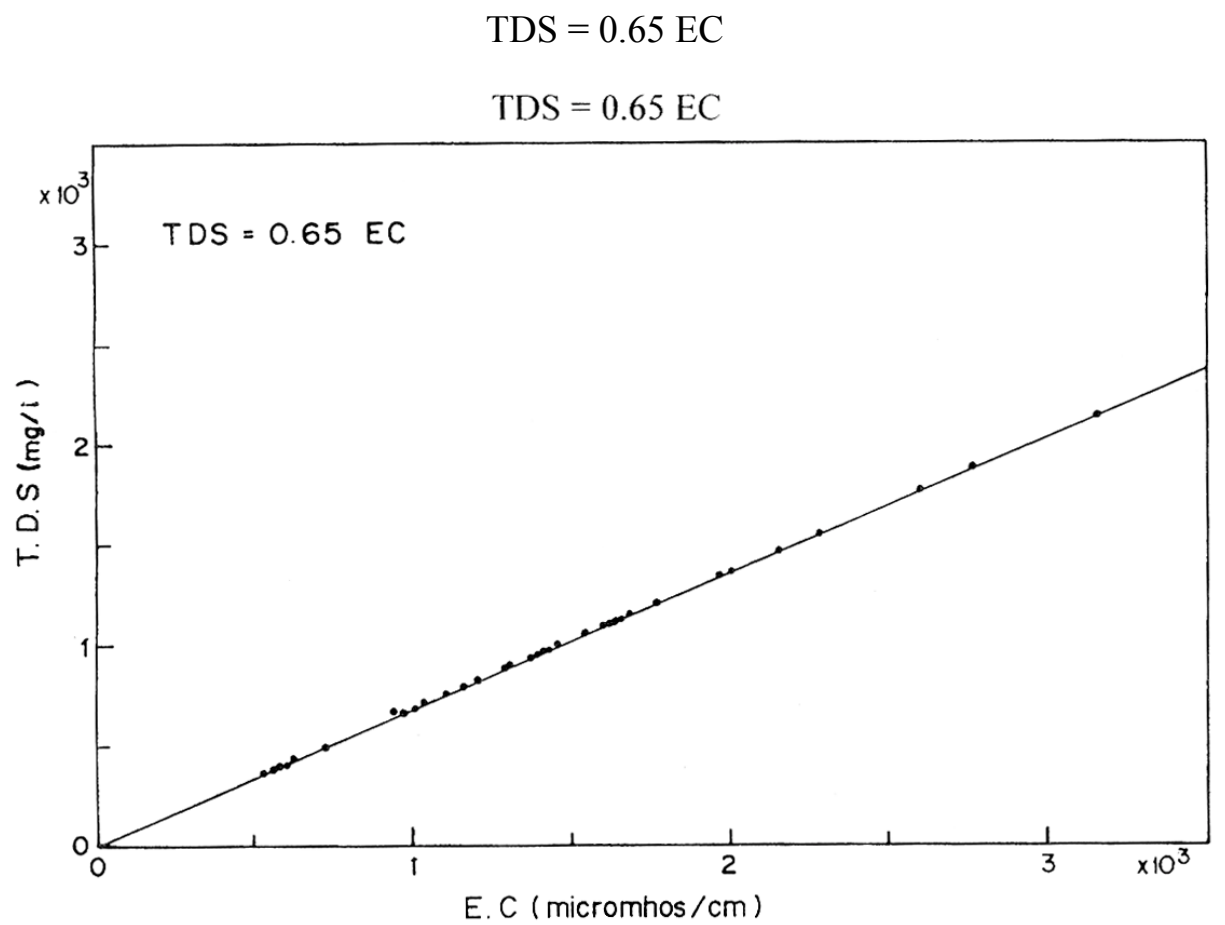

It should be noted that TDS and EC are measured in $\mathrm{mg} / 1$ and $\mu \mathrm{S} / \mathrm{cm}$, respectively. This equation help to estimate TDS values from field measured EC values in a very rapid and economical manner.

Since the $\mathrm{pH}$ value is essential for the interpretation of groundwater chemistry (Water Practice Manuals, 1986), it was measured in the field for all the wa- 
ter samples. The $\mathrm{pH}$ values in the study area lie within the WHO standard with an average of 7.5. From Table 1, it is possible to deduce that all the $\mathrm{pH}$ values for the water samples are more or less similar and lies within the permissible limits. The water is slightly alkaline in the area and it could be related to the $\mathrm{CO}_{2}$ or the bicarbonate contents.

\section{Groundwater Evaluation}

As the quality of water determines its suitability for the various uses, and since wadi Tharad is a developing area with the need of water for drinking and irrigation purposes, it is necessary to specifically discuss the groundwater evaluation. On the basis of the chemical analysis data which were carried out during this study and according to WHO standards (Table 2), it seems that the water with values less than or just above the WHO standards can be used safely for drinking purposes.

In addition, the suitability of water for irrigation, the Sodium Adsorption Ratio (SAR) standards published by the Salinity Laboratory of the Department of Agriculture in 1954 were also considered. Table 1 shows that the SAR is between 1.15 and 5.34. According to the classification of groundwater for irrigation purposes (Todd, 1980), all the groundwater in Wadi Tharad area can be considered as excellent for irrigation purposes.

\section{Conclusions and Recommendations}

The following specific conclusions can be drawn from this study:

1. The groundwater in the study area is generally soft, potable and good for domestic and other purposes.

2. The water can be considered to be of the alkalinity type.

3. The high salinity of the water in the area may be due to high concentration of calcium with respect to magnesium.

4. From the hydrochemical facies points of view, there are two water types: calcium-magnesium-sulfate-chloride water and calcium-magnesium-bicarbonate water.

5. It is recommended that the water quality at this area should be frequently monitored to detect any changes in the water quality with time.

\section{Acknowledgement}

The authors would like to thank Prof. Zekai Sen for reviewing the manuscript and providing valuable suggestions. 


\section{References}

Asfri, S.A. (1993) Characteristics of water bearing formation at Wadi Tharad, south of Saudi Arabia, B.Sc. Project, (Arabic). Faculty of Earth Sciences, Jeddah, Saudi Arabia, 99 p.

Davis, S.N. and DeWiest, R.J.M. (1976) Hydrogeology. John Wiley and Sons. New York, 463 p.

Driscoll, F.G. (1987) Groundwater and wells. 2nd ed., Johnson Division, St. Paul, Minnesota 55112, U.S..

Freeze, R.A. and Cherry, J.A. (1979) Groundwater. Prentice-Hall, Inc., Englewood Cliff, New Jersey, $604 \mathrm{p}$.

Greenwood, W. R. (1975) Geology of the Al Aqiq Quadrangle, Sheet 20/41 D, Kingdom of Saudi Arabia, Ministry of Petroleum and Mineral Resources, Directorate General of Mineral Resources.

Todd, D.K. (1980) Groundwater Hydrology. 2nd-ed., John Wiley \& Sons, Inc. U.S.A, 535 p.

Ministry of Agriculture and Water (1984) Water Atlas of Saudi Arabia, Riyadh, Saudi Arabia, $112 \mathrm{p}$.

Water Practice Manuals (1986) Groundwater: Occurrence, Development and Protection, T. W. Brandon (edit.), The Institution of Water Engineers and Scientists, London, 615 p.

World Health Organization (1984) Guidelines for drinking water quality, 1, Recommendations. Geneva: WHO. 


\title{
تقييـم نوعيـة الميـاه الجلوفيـة في منطقــة وادي ثـراد جنوب المملكة العربية السعودية
}

\author{
مسعود عيد الاحمدي * و ناصر الجحدلي

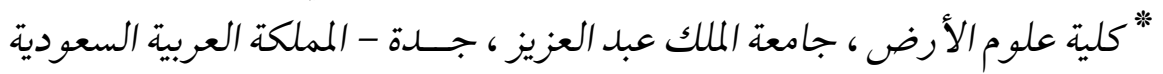

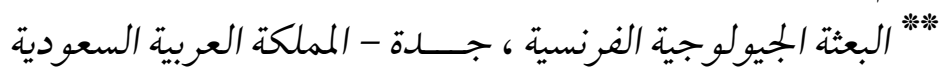

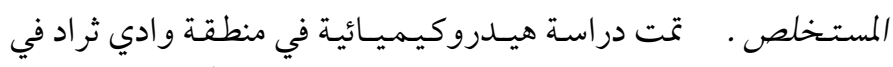

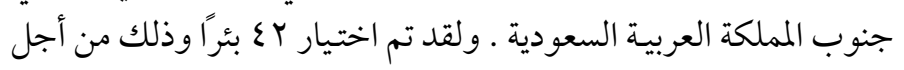
أخذ عينات من مياه تلك الآبار .

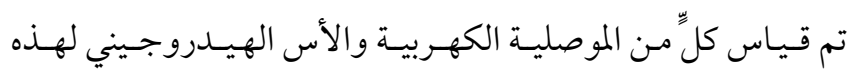

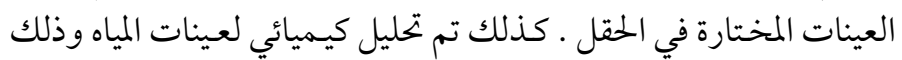

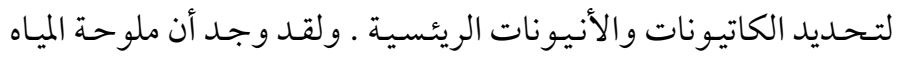

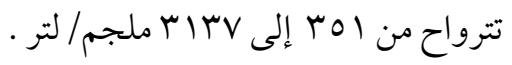

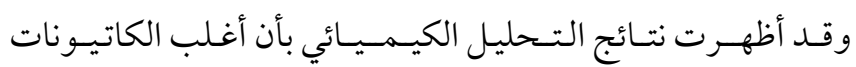

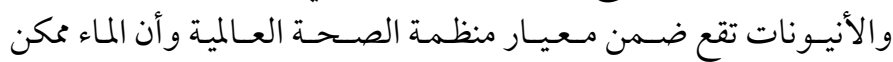
استخدامه بأمان في بعض الأماكن ـ المياه الجوفية في منطقة الدراسة أمكن

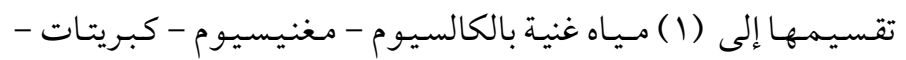

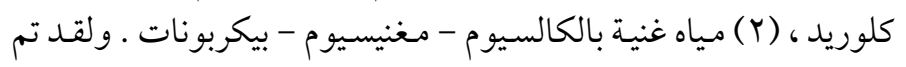

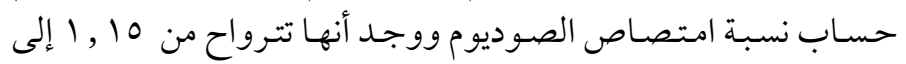

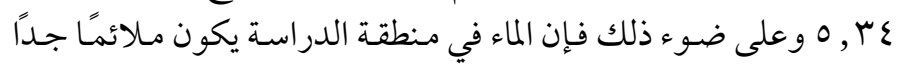
للأغراض الزراعية . 
والباريوم) والعناصر الأرضية النادرة ـ تتميز سحنة الإبيدوت - كوارتز

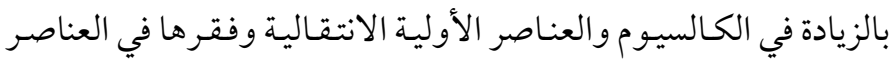

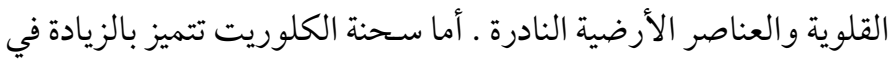

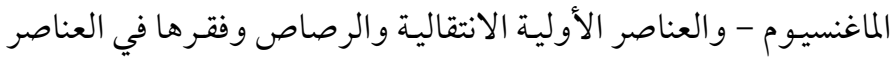
القلوية الأرضية ، و الفوسفور و الاسترنشيوم والعناصر الأرضية النادرة . ومن خلال هذه الدراسة وجد أن عناصر التيتانيوم والألمنيوم و الحديد

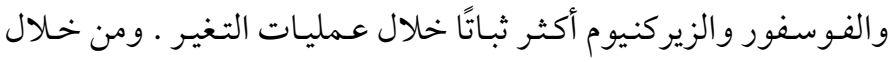

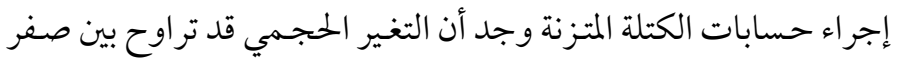

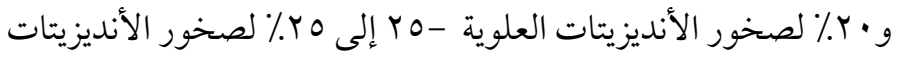

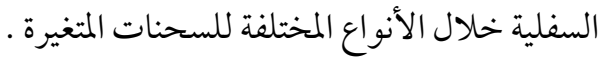

